\title{
Knowledge of preparatory students working in Agriculture about work hazards
}

\section{Omima R. Rehap :}

Assistant lecturer of Community Health Nursing

Faculty of Nursing, Tanta University

\section{Bassima E. Gowayed,}

Professor of Community Health Nursing

Faculty of Nursing, Tanta University

\section{Ikbal F. El-shafie}

Professor of Community Health Nursing,

Faculty of Nursing, Tanta University

\section{Amaal M. El-Zeftawy:}

Lecturer of Community Health nursing

Faculty of Nursing, Tanta University

\begin{abstract}
Child labor is alarmingly prevalent in Egypt .Child agricultural workers are at a greater risk than adult workers. Furthermore, occupational hazards and work conditions may have permanent effects on the growth and development of children. Several public health strategic interventions are required for effective prevention and control of child labor in agriculture. Aim of the study: to assess the knowledge of preparatory school students working in agriculture about work hazards. Material and Methods: this study was conducted in five preparatory governmental schools (including both sexes) at five villages affiliated to Kafer ELzayat city Gharbia Governorate, Egypt as a representative of rural environment. Tool: A structured questionnaire sheet was developed and used by the researcher; it included data regarding socio-demographic data related to the students, past working experience of the child, previous complaints, history of hazards, safety and protective measures and knowledge of students about agriculture work hazards. Results: most of the studied students' source of information was from their parents and family and the majority of studied students had poor total knowledge score regarding the agriculture hazards.
\end{abstract}




\section{Conclusion and recommendations:}

The present study revealed that, the majority of studied students identified the elements of different agriculture hazards but had lack of knowledge regarding its health effects. It is recommended that the working children should receive full information and training from their employers about occupational hazards related to agricultural work. Such training should be conducted regularly and be understandable by children.

Key words: Child labor, Egypt, knowledge

\section{Introduction}

Children are the most important age group in all societies. Health status and health behavior of later life are laid down at this stage. No one can deny their rights to grow and develop in a healthy and normal manner, to benefit from social security including adequate nutrition, adequate housing, recreation and medical services, as well as to receive education and be protected against all forms of neglect and exploitation $^{(1,2)}$.

Child labor is a global problem that appears to affect a major proportion of children in the developing world. The International Labor Organization defines child labor as work that deprives children of their childhood, their potential and their dignity. It is also harmful to The physical and mental development and interferes with their schooling by depriving them from the opportunity to attend school, obligating them to leave school prematurely or requiring them to attempt to combine school attendance with executively long and heavy work ${ }^{(3,4)}$.There are many factors responsible for this problem. These factors are mainly poverty, lack of education, unemployment, and exploitation by lazy parents. Others factors include school dropout, maladjustment in the family, broken family, death of parents and child of illegitimate pregnancy ${ }^{(5)}$.

In Egypt the reasons given by child workers themselves in studies were educational failure and a desire to learn a profession for boys, where girls cited economic factors like a wish to earn their own money or contribute to family income. Another reason is that parents wish to keep their children occupied and off streets. Furthermore, many families 
think that sending their children to work is acceptable. They view child labor as child work only, not hazardous and as a way to learn a skill ${ }^{(6,7)}$.

The International Labor Organization in 2002 estimated that nearly 250 million children were engaged in child labor around the world. The vast majority of them $70 \%$ were working in agriculture. Of the four most dangerous industries (agriculture fishing, mining, construction) agriculture has the highest morbidity and mortality rate ${ }^{(5)}$. In Egypt it is difficult to gather accurate statistic on child labor. In 2002 it was estimated that over 2 million children were engaged in child labor from as young as the age of 4 years who work as street venders, domestic workers, agricultural laborers and factory workers. About 73 $\%$ of the working children in Egypt are employed in agriculture ${ }^{(8) .}$

According to the International Labor Organization's report in 2002 on child labor, the number of children working in agriculture is nearly ten times that of children involved in factory work such as garment manufacturing, carpet weaving and others industries. Yet, despite the difficult nature of their work, children working in agriculture have received little attention compared to child labor in manufacturing for export or children involved in commercial sexual exploitation ${ }^{(9)}$.

Child agricultural workers may suffer from considerable physical, biological, chemical, and psychological hazards. Child agricultural workers frequently work for long hours in scorching heat, haul heavy loads of product, and exposed to toxic pesticides and suffer high rates of injury from sharp knives and others dangers tools. Their work is harsh and violates their rights ${ }^{(10,11)}$. The employment of young children is a serious problem particularly in rural areas where it is not unusual for children to start work at the age of 5 to 6 years. Finally child labor is used to refer to anyone who is a child (under the age of 18) who is working for payment and sometimes unpaid work ${ }^{(12)}$.Egypt National low set appropriate limits on both the ages and hours at which children can work, and if enforced would help to protect children from abusive labor conditions ${ }^{(13)}$.

In Egypt, children represent a very large group of the Egyptian population pyramid. The population of Egypt, (2008), is estimated to be 80 million 
inhabitants. The distribution of population by age indicates that those below the age of 15 years represent about $37.5 \%$ of the total population. Egypt has a history of child labor problems. Poverty has driven many children younger than the minimum working age of 14, to join the labor force. At the same time, it was difficult to gather accurate statistic of the number of child work in Egypt. The annual activity report on 2007 stated that the number of working children in Egypt is estimated to be between 1.3 to 3 million. They are accepting the lowest wages and the hard and inhuman working condition. Child labor in Egypt are divided between different sectors with the agricultural sector representing the highest percentage about $78 \%$, in industrial sector, about $14.9 \%$, in commercial $6 \%$, and in the service sector $1.14 \%^{(14,15)}$.

In Egypt (2005), approximately 9.5 percent of boys and 3.7 percent of girl's ages 5 to 14 were working. A large proportion of working children are found in agricultural sector, where children are hired each year for the cotton harvest. Children are also found working on construction sites and in light industry (16-18,). Government studies in Egypt reveal that the percentage of working children is higher in rural than urban areas. Agriculture considered one of the most hazardous occupations and also young ages are more likely to work in agriculture. According to Human Right Watch in 2001, over one million Egyptian children between the ages of 7 and 12 years are hired each year to work to aid in controlling cotton leaf worm $(14,19,20)$

Children work in farms especially in the cotton and rice farms during harvest season, exposed to deadly pesticides, as their bodies easily absorb these dangerous chemicals. The children in the cotton fields work for about 5 to 7 pounds per day and their ages vary from 7 to 15 years. They don't enjoy legal protections, social insurance or official supervision ${ }^{(14,21)}$. Most of the child workers in Egypt are employed in seasonable work in cotton fields, during the summer holiday months. The Minister of Agriculture fails to uphold the legal minimum age of 12 for seasonable training. Each year over one million children between the ages of seven and twelve are hired by Egypt's 
agriculture cooperatives to take part in cotton pest management. They work eleven hours a day, including a one to two hour break, seven days a week, far in excess of limits set by the Egyptian child low ${ }^{(22,23)}$.

Child workers also force routine beating by their foramen as well as exposure to heat and pesticides. These conditions violates Egypt's obligation under the convention on the rights of the child, to protect children from ill treatment and hazardous employment. They work many hours that expand between sunrise and sunset such as crop gathering and looking after for animals. According to Human Rights Watch's report in 2001, the children were exclusively recruited for the work because they could be paid less than adults, more easy going, obedient, and had the appropriate height for removing damaged leaves ${ }^{(19,24)}$. The National Council for Childhood and Motherhood (NCCM 2002) stated that working children revenue makes up to 29 percent of his family income. About 73 percent of working children work in agriculture. The NCCM survey stated that about 81.5 percent of working children in Egypt are still enrolled in schools and
54 percent work only in the summer vocation ${ }^{(25)}$.

The future of a community is in the wellbeing of its children, so it becomes imperative for the health of the nation to protect its children from premature labor which is a hazardous to their mental, physical, educational and spiritual development needs ${ }^{(26)}$.The extraordinary numbers of children working in agriculture, worldwide and the severe abuse they endure demand that all governments, Non Governments, community, parents and employers all cooperate together and prioritize their working for protecting child agriculture workers as a part of their strategies to end child labor ${ }^{(27)}$.

The community health nurse can assume many roles while serving in different community agencies. Thus, her preventive role can be provided according to the three levels of prevention; primary, secondary and tertiary level of prevention ${ }^{(28)}$.Finally child labor especially in agriculture is a phenomenon in rural areas which need to be studied from the community health nurses. Thus, it is very important to study the knowledge of the working students about work hazards in order to 
facilitate their role in dealing with working condition, and workplace hazards.

\section{Aim of the Study}

The aim of the study was to assess the knowledge of preparatory school students working in agriculture about work hazards.

\section{Materials and Method}

\section{Materials}

\section{Study design:-}

A cross sectional descriptive design was used in this study.

\section{Setting:}

The study was conducted in five preparatory governmental schools (including both sexes) at five villages affiliated to Kafer ELzayat city, Gharbia Governorate, Egypt as a representative of rural environment. The villages were selected as follow:

- A list of all villages with preparatory schools in Kafer El Zayat district was prepared by the researcher with the assistance from the Manager of the Educational Directorate in Kafer El Zayat. The number of villages was 28 villages.

- Accordingly, five villages with preparatory schools were selected by simple random sample technique using fish bowl draw to represent the study setting.

- The schools selected in the study were:-

1-Kalip Ebiar Preparatory School in Kalip Ebiar village.

2-Gamal El Shafie preparatory school in EL Naharia Village.

3-Nabil EL Daharawy preparatory school in Ebiar village.

4-Saad EL Hosary preparatory school in Sedema village.

5-Kafer EL Maharoq preparatory school in Kafer EL Maharoq village.

\section{Sample:-}

- The number of students working in agriculture was estimated form each school by asking the students in the classes. The total number of students working in agriculture in the selected schools was 1338 students. They distributed in schools as follows:-200 students in Kalip Ebiar Preparatory School.

-233 students in Gamal El Shafie preparatory school.

-300 students in Kafer EL Maharoq preparatory school

-150 students in Saad EL Hosary preparatory school. 
-455 students in Nabil EL Daharawy preparatory school.

- In each school a list was done of students working in agriculture, it included their names, grades and classes.

- The total number of the students included in the study was 510 students. From each school 102 students were selected by using disproportionate stratified random sample.

- Thirty four student were selected from each grade (first, second and third) with simple random technique by using fish bowl draw.

\section{Tool of the study:}

A structured questionnaire sheet was developed by the researcher in order to collect the necessary data. It included the following parts:-

\section{Part (1):}

Socio-demographic data related to the students, this included: - age, sex, grade, parents' education, parents' occupation, family income, family size, housing condition and numbers of rooms.

\section{Part (2):}

- Past working experience of the students which included: age of starting work, working days per week, reasons for initiating child work, working hours, rest periods, working during studying and effects on study, seasons of work, nature and tasks performed by the working students.

-Previous complaints related to work condition and work environment.

- History of hazards faced during work -Safety and protective measures used by students to protect themselves and reasons for not using safety and protective measures.

\section{$\underline{\text { Part (3) }}$}

Knowledge of students about agriculture work hazards which included:-

1-Physical hazards: These included: exposure to heat (hot or cold), humidity, noise, and working during night.

2-Chemical hazards: These included:exposure to dusts and straws from crushing crops, exposure to fumes, gases, exposure to pesticides and fertilizer.

3-Mechanical hazards: These included: - using different agriculture machines, working long hours standing or bending the head and the neck climbing trees for picking the crops, and experience in using agriculture machines. 
1- Biological hazards: These included: - dealing with animals biting from mosquito and flies, eating fruits and vegetables directly without washing, dealing with water canals in irrigation and using it in washing, dealing and disposable of animal's excreta and breeding of rats in fields.

2- Psychological hazards: These included: - dealing with stressful situation, abuse during work, problems with others, unsatisfaction with working, forced labor, exposure to emotional pressures and anxiety.

3- Personal hazards: These included: - risk factors that increase the rate of hazards as young age, inexperience, physical illness and fatigue, stress, careless and misestimating the hazards.

\section{Method}

\section{1- Obtaining approval.}

- Before conducting the study, a written permission letter was obtained from the Faculty of Nursing to the Director of the Educational Bureau in Kafer ELZayat city in order to attain an approval to carry out the study.
Official permission was obtained from the Educational Bureau in Kafer El Zayat city to the head masters of each selected school for conducting the study.

\section{2- Developing the tool.}

-The structured questionnaire sheet was developed based on the literature review (29-32)

The tool was distributed to jury from nursing and medicine, fields to measure its face and content validity and accordingly modification was done. The jury consisted of three professors as follows: - one professor from Faculty of Nursing, Tanta University, two professors from Faculty of Medicine, Tanta University.

\section{3- The Pilot study.}

A Pilot study was carried out before embarking on the field work this was done on 20 preparatory school students working in agriculture. Those students were excluded from the study sample.

- The purpose of the pilot study was to test the reliability of the tool, clarity and organization and to determine the length of time needed to collect the data from each student accordingly modification was done. In order to test the 
reliability of the tool, test - retest was done .The pilot study conducted twice, 2 weeks apart. The first test done and analyzed, its results were $76.74 \%$ and the second retest was $76.13 \%$.

\section{4- The actual study.}

-The collection of data was done during the period from October to December 2010.

-Data collection schedule was done by the researcher based on the free classes in the day for collecting the data.

-The researcher was available in the schools three days /week from 9 am to1 pm.

-Data collection obtained from the students by the researcher in the morning time. The researcher took 5 to 6 students from classes into the library and distributed the questionnaire to them.

The purpose of the study was explained to the selected students.

-Informed consent was obtained form the chosen students to participate into the study before starting to fill the questionnaire sheet.

-The researcher sat with the students, explained the sheet and asked about any difficult or misunderstanding question to explain it.

-The average time needed for each student to fill the sheet ranged from 2030 minute and the number of filled sheet per day was about $18-25$ sheet. After the students filled the sheet the researcher ensured that all questions were answered and asked the students to fill any missed question.

\section{Limitation of the study:}

Nearly $20 \%$ of female students refused to participate into the study, fearing from unknown consequences. Other students were selected randomly from the list to fulfill the required number.

\section{Statistical analysis}

1-The knowledge of the studied students regarding agricultural work hazards was analyzed and scored as follows:-

Each correct item for each hazard was given one score and any wrong answer was given zero, then the total score of each hazard was calculated as follows:-Physical hazards score was17 points -Chemical hazards score was 15 points -Mechanical hazards score was13 points

-Biological hazards score was 21 points 
Psychological hazards score was 17 points

-Personal hazards score was 13 points

-Total score of all hazards was 96 points

2- The knowledge score of the studied students regarding agricultural work hazards had been classified into three categories as follows:-

-Poor knowledge: $<50 \%$ of the total knowledge score

-Average knowledge: $50 \%-65 \%$ of the total knowledge score

-High knowledge: $>65 \%$ of the total knowledge score

3-The collected data was organized, tabulated and statistical analyzed using SPSS software statistical computer package version 16.For quantitative data, the range, mean, and standard deviation were calculated.

\section{Results}

Table (1) represents the sociodemographic characteristic of the studied students. The majority $(72.75 \%)$ of the students were aged less than 15 years old, with a mean $13.85 \pm$ 1.13 years. Slightly less than three quarters $(73.9 \%)$ were males.

As regard to the number of persons living with the students in the home the table shows that it ranged from 1-28 with mean $6.46 \pm 3.41$ members. Almost two thirds (65.88\%) were living with five to ten members.

Regarding the number of brothers \& sisters, the majority $(87.65 \%)$ of the studied students had less than five brothers and sisters, with a mean $2.8 \pm$ 1.37. Nearly one third $(33.9 \%)$ of the studied students were the first child in the birth order, while nearly one quarter (27.5\% and $22.7 \%$ respectively) were the second and third birth order. The table shows that majority $(91.4 \%)$ of the studied students were living with their parents.

As regard to fathers' education, it was observed that more than one quarter $(29.6 \%)$ of them were either illiterates or just read and write, while about $31.8 \%$ of them had basic education (primary \& preparatory) and only $15.3 \%$ of them were university educated.

Regarding the fathers' occupation of the studied students, more than one quarter $(27.6 \%$ and $27.1 \%)$ of them were farmers and employees respectively. In relation to mothers' education nearly half of them $(48.8 \%)$ were either illiterates or just read and write. The 
majority $(85.7 \%)$ of the studied student's mothers were house wives. Regarding the family income per month, it was observed that more than half $(61.0 \%)$ of the studied students mentioned that the income was just sufficient, while only $21.2 \%$ mentioned that income was insufficient. Three quarters $(75.4 \%)$ of the studied students their source of income was from fathers' work.

In relation to the type of house, it shows that nearly half $(47.8 \%)$ of the studied students were owing a house. In relation to the number of rooms, the majority $(89.80 \%)$ of the studied students reported that they had less than 5 rooms with mean $3.43 \pm 0.986$ rooms.

Table (2) represents the distribution of students past experience in agricultural work. It shows that more than half $(58.04 \%)$ of the studied students were working in agriculture before 10 years while about $41.96 \%$ started work from 10 years or more. The mean age of starting work was $8.79 \% \pm 2.09$ years. The table shows that more than two thirds $(68 \%)$ of studied students didn't work during school. the majority of the studied students $(84.5 \%)$ mentioned that work had no effect on their study
Among those who were affected by their work, $87.34 \%$ mentioned that they failed in study.

As regard to the reasons for working in agricultural work, it shows that (43.9\%) of the studied students reported to help their fathers' in the work and more than one quarter $(27.5 \%)$ reported that to be independent. It is observed that two third $(66.5 \%)$ of the studied students worked in their families fields while $16.9 \%$ and $16.7 \%$ of them were working in relatives lands and paid from others respectively. The table shows that most $(70.18 \%)$ of the students who were working at others fields (relatives or paid) taking money, ranged between 15 35 pound per day with mean $24.59 \pm 4.92$.

As regard to the reasons for choosing agricultural work. The table shows that nearly half $(46.1 \%)$ of the studied students, choose the agricultural work because it is their fathers' profession. The majority $(72.2 \%)$ of the studied students reported working in picking crops .It shows that nearly half of the studied students (47.1\%) only work during summer \& vocations while about nearly one third $(32.5 \%)$ were working occasionally. 
As regard to the number of working hours per day, It shows that $(42.5 \%)$ of the studied students worked less than four hours and about one third (35.5\%) of them worked more than 6 hours. The entire studied students were taking a rest period during the work, nearly half of them (47.5\%) were taking half an hour while about one third (33.9\%) were taking one hour during the day. The table shows that three quarter (75.1\%) of the studied students were taking a weekend.

The same table shows that more than one third $(37.4 \%)$ of the studied students had no complaint from agricultural work, while nearly one quarter $(26.7 \%$ and $23.7 \%)$ of them complained from fatigue, and beating \&kicking respectively from their supervisors or fathers.

As regard to the past hazards from agricultural work, it was observed that $44.12 \%$ of the students exposed to past hazards from the work.

In relation to wearing safety clothes, it shows that nearly three quarter $(74.5 \%)$ of the students was wearing safety clothes, of them $54.21 \%$ were using a hat, while $35.53 \%$ used gloves. Nearly two third $(69.23 \%)$ of the studied students who were not wearing safety clothes reported that they were unavailable. Half $(50.39 \%)$ of the studied students reported that their supervisors provided the safety clothes. More than half $(57.06 \%)$ of the studied students reported that they were not having enough money for purchasing protective clothes.

Figure (1):- show the distribution of studied students according to their responses regarding their sources of information about agriculture hazards. It show that most of the studied students $(69.80 \%)$ their source of information from their parents and family, while only $17.06 \%$ and $14.90 \%$ were from computers, internet and agricultural supervisors respectively.

Table (3) shows the distribution of the total score of knowledge for each agriculture hazards. Regarding the different agriculture hazards the table shows that the majority of studied students had poor knowledge score regarding the different agriculture hazards. Only $6.3 \%$ had average score for both chemical and personal hazards.

Table (4) and figure (2) represents the distribution of studied students according to the total score of 
knowledge of the agriculture hazards.

The table shows that the majority $(99.2 \%)$ of the studied students had poor knowledge scores regarding the total agricultural hazards while only
$0.8 \%$ had average knowledge score, with mean $20.88 \pm 9.1$ and ranged between (0-56) from the total score of all hazards that had been 96 points.

Table (1):- Distribution of studied students accords to their Socio-demographic characteristics.

\begin{tabular}{|c|c|c|}
\hline \multirow[t]{2}{*}{ Socio-Demographic characteristics } & \multicolumn{2}{|c|}{$\begin{array}{l}\text { studied students } \\
(\mathbf{N}=\mathbf{5 1 0})\end{array}$} \\
\hline & $\mathrm{N}$ & $\%$ \\
\hline \multirow{2}{*}{$\begin{array}{l}\text { Age: } \\
<15 \text { years } \\
\geq 15 \text { years } \\
\text { Mean } \pm \text { SD } \\
\text { Range } \\
\end{array}$} & $\begin{array}{c}371 \\
139\end{array}$ & $\begin{array}{r}72.75 \\
27.25\end{array}$ \\
\hline & \multicolumn{2}{|c|}{$\begin{array}{c}13.85 \pm 1.13 \\
12-17 \\
\end{array}$} \\
\hline $\begin{array}{l}\text { Sex: } \\
\text { Male } \\
\text { Female }\end{array}$ & $\begin{array}{l}377 \\
133\end{array}$ & $\begin{array}{l}73.9 \\
26.1\end{array}$ \\
\hline $\begin{array}{l}\text { Number of persons lives with the students } \\
\text { in home: } \\
<5 \\
5-10 \\
>10\end{array}$ & $\begin{array}{c}119 \\
336 \\
55\end{array}$ & $\begin{array}{l}23.33 \\
65.88 \\
10.78\end{array}$ \\
\hline $\begin{array}{l}\text { Mean } \pm \text { SD } \\
\text { Range }\end{array}$ & \multicolumn{2}{|c|}{$\begin{array}{c}6.46 \pm 3.41 \\
1-28\end{array}$} \\
\hline \multirow{2}{*}{$\begin{array}{l}\text { Number of brothers } \& \text { sisters: } \\
<5 \\
\geq 5 \\
\text { Mean } \pm \mathrm{SD} \\
\text { Range }\end{array}$} & $\begin{array}{c}447 \\
63\end{array}$ & $\begin{array}{l}87.65 \\
12.35\end{array}$ \\
\hline & \multicolumn{2}{|c|}{$\begin{array}{c}2.8 \pm 1.37 \\
0-8\end{array}$} \\
\hline $\begin{array}{l}\text { Students' birth order: } \\
1^{\text {st }} \\
2^{\text {nd }} \\
3^{\text {rd }} \\
4^{\text {th }} \text { or more }\end{array}$ & $\begin{array}{c}173 \\
140 \\
116 \\
81\end{array}$ & $\begin{array}{l}33.9 \\
27.5 \\
22.7 \\
15.9\end{array}$ \\
\hline $\begin{array}{l}\text { The student lives with: } \\
\text { The parents } \\
\text { Mother } \\
\text { Father }\end{array}$ & $\begin{array}{c}466 \\
41 \\
3\end{array}$ & $\begin{array}{c}91.4 \\
8 \\
0.6\end{array}$ \\
\hline $\begin{array}{l}\text { Fathers' education: } \\
\text { Read and write or illiterates } \\
\text { Basic education }\end{array}$ & $\begin{array}{l}151 \\
162\end{array}$ & $\begin{array}{l}29.6 \\
31.8\end{array}$ \\
\hline
\end{tabular}




\begin{tabular}{|c|c|c|}
\hline $\begin{array}{l}\text { Secondary education } \\
\text { University education }\end{array}$ & $\begin{array}{r}119 \\
78\end{array}$ & $\begin{array}{l}23.3 \\
15.3\end{array}$ \\
\hline \multicolumn{3}{|l|}{ Fathers' occupation: } \\
\hline Farmers & 141 & 27.6 \\
\hline Farmer \& anther work & 71 & 13.9 \\
\hline Technical workers & 94 & 18.4 \\
\hline Employees & 138 & 27.1 \\
\hline Manual works & 26 & 5.1 \\
\hline Not working & 6 & 1.2 \\
\hline Others(retired or dead) & 34 & 6.7 \\
\hline \multicolumn{3}{|l|}{ Mothers' education: } \\
\hline Read and write or illiterate & 249 & 48.8 \\
\hline Basic education & 118 & 23.2 \\
\hline Secondary education & 104 & 20.4 \\
\hline University education & 39 & 7.6 \\
\hline \multicolumn{3}{|l|}{ Mothers' occupation: } \\
\hline Housewife & 437 & 85.7 \\
\hline Workers & 24 & 4.7 \\
\hline Employee & 38 & 7.5 \\
\hline Farmer & 11 & 2.2 \\
\hline \multicolumn{3}{|l|}{ Family income per month } \\
\hline Not sufficient & 108 & 21.2 \\
\hline Sufficient & 311 & 61.0 \\
\hline Sufficient and more & 91 & 17.8 \\
\hline \multicolumn{3}{|l|}{ *Source of income } \\
\hline Fathers' work & 384 & 75.4 \\
\hline Mothers' work & 19 & 3.7 \\
\hline Parents together & 57 & 11.2 \\
\hline Parents \& children & 22 & 4.3 \\
\hline Children only & 17 & 3.4 \\
\hline lands and properties & 26 & 5.1 \\
\hline Aids and helpers & 7 & 1.4 \\
\hline \multicolumn{3}{|l|}{ Type of house } \\
\hline Owing a house & 244 & 47.8 \\
\hline Rent flat & 11 & 2.2 \\
\hline Shared house & 34 & 6.7 \\
\hline Having a flat & 221 & 43.3 \\
\hline \multicolumn{3}{|l|}{ Number of rooms: } \\
\hline$<5$ & 458 & 89.80 \\
\hline$\geq 5$ & 52 & 10.20 \\
\hline $\begin{array}{l}\text { Mean } \pm \text { SD } \\
\text { Range }\end{array}$ & \multicolumn{2}{|c|}{$\begin{array}{c}3.43 \pm 0.986 \\
1-8\end{array}$} \\
\hline
\end{tabular}

* More than one answer was allowed. 
Table (2):- Distribution of studied students accords to their past experience in agriculture work.

\begin{tabular}{|c|c|c|}
\hline \multirow{2}{*}{ Child past experience in agriculture work: } & \multicolumn{2}{|c|}{$\begin{array}{l}\text { studied students } \\
\qquad(\mathrm{N}=510)\end{array}$} \\
\hline & $\mathrm{N}$ & $\%$ \\
\hline $\begin{array}{l}\text { Age of starting agricultural work: } \\
<10 \text { years } \\
\geq 10 \text { years }\end{array}$ & $\begin{array}{l}296 \\
214\end{array}$ & $\begin{array}{l}58.04 \\
41.96\end{array}$ \\
\hline $\begin{array}{l}\text { Mean } \pm \text { SD } \\
\text { Range }\end{array}$ & \multicolumn{2}{|c|}{$\begin{array}{c}8.79 \pm 2.09 \\
5-14\end{array}$} \\
\hline $\begin{array}{l}\text { Working during school: } \\
\text { Yes } \\
\text { No }\end{array}$ & $\begin{array}{l}163 \\
347\end{array}$ & $\begin{array}{l}32.0 \\
68.0\end{array}$ \\
\hline $\begin{array}{l}\text { Work effects on the study: } \\
\text { Yes } \\
\text { No }\end{array}$ & $\begin{array}{c}79 \\
431 \\
\end{array}$ & $\begin{array}{l}15.5 \\
84.5\end{array}$ \\
\hline $\begin{array}{l}\text { If yes mention this effect: } \\
\text { Failed in study } \\
\text { Fatigue } \\
\text { lose time } \\
\text { Un concentration }\end{array}$ & $\begin{array}{l}69 \\
3 \\
4 \\
3\end{array}$ & $\begin{array}{l}87.34 \\
3.80 \\
5.06 \\
3.80\end{array}$ \\
\hline $\begin{array}{l}\text { Reasons for working in agriculture: } \\
\text { Help in family income } \\
\text { to expense on myself } \\
\text { Help the father in the work } \\
\text { according to parent desire } \\
\text { To be independent }\end{array}$ & $\begin{array}{c}69 \\
35 \\
224 \\
42 \\
140\end{array}$ & $\begin{array}{c}13.5 \\
6.9 \\
43.9 \\
8.2 \\
27.5\end{array}$ \\
\hline $\begin{array}{l}\text { Working in: } \\
\text { family's fields } \\
\text { relatives fields } \\
\text { Paid on others }\end{array}$ & $\begin{array}{c}339 \\
86 \\
85\end{array}$ & $\begin{array}{l}66.5 \\
16.9 \\
16.7 \\
\end{array}$ \\
\hline $\begin{array}{l}\text { Working with others or relatives, paid or not: } \\
\text { paid } \\
\text { not paid }\end{array}$ & $\begin{array}{c}120 \\
51\end{array}$ & $\begin{array}{l}70.18 \\
29.82\end{array}$ \\
\hline $\begin{array}{l}\text { If you paid ,what daily allowance LE/day } \\
\text { Mean } \pm S D \\
\text { Range }\end{array}$ & \multicolumn{2}{|c|}{$\begin{array}{c}24.59 \pm 4.92 \\
15-35\end{array}$} \\
\hline $\begin{array}{l}\text { Reasons of choosing working in agriculture: } \\
\text { love it and appropriate to me } \\
\text { it is available to me } \\
\text { Because it's my father's profession } \\
\text { because my relative work in it }\end{array}$ & $\begin{array}{c}100 \\
81 \\
235 \\
94\end{array}$ & $\begin{array}{l}19.6 \\
15.9 \\
46.1 \\
18.4\end{array}$ \\
\hline
\end{tabular}


Cont.

\begin{tabular}{|c|c|c|}
\hline $\begin{array}{l}\text { Nature of work in the field: } \\
\text { Picking crops } \\
\text { spraying pesticides } \\
\text { collecting worm from plant } \\
\text { Planting grains }\end{array}$ & $\begin{array}{c}368 \\
17 \\
70 \\
55\end{array}$ & $\begin{array}{c}72.2 \\
3.3 \\
13.7 \\
10.8\end{array}$ \\
\hline $\begin{array}{l}\text { Times of working in agriculture } \\
\text { Daily during the year } \\
\text { During summer \& vocations } \\
\text { At the time of picking crops only } \\
\text { According to occasions }\end{array}$ & $\begin{array}{c}39 \\
240 \\
65 \\
166\end{array}$ & $\begin{array}{l}7.6 \\
47.1 \\
12.7 \\
32.5\end{array}$ \\
\hline $\begin{array}{l}\text { Working hours during the day } \\
\text { Less than } 4 \text { hours } \\
\text { from } 4 \text { to } 6 \text { hours } \\
\text { more than } 6 \text { hours }\end{array}$ & $\begin{array}{l}217 \\
112 \\
181\end{array}$ & $\begin{array}{l}42.5 \\
22.0 \\
35.5\end{array}$ \\
\hline $\begin{array}{l}\text { Taking rest period during the work } \\
\text { Yes } \\
\text { No }\end{array}$ & $\begin{array}{c}510 \\
0\end{array}$ & $\begin{array}{c}100 \\
0\end{array}$ \\
\hline $\begin{array}{l}\text { If the answer is yes, the duration of rest period } \\
\text { Half an hour } \\
\text { hour } \\
\text { more than hour }\end{array}$ & $\begin{array}{c}242 \\
173 \\
95\end{array}$ & $\begin{array}{l}47.5 \\
33.9 \\
18.6\end{array}$ \\
\hline $\begin{array}{l}\text { Taking a weekend } \\
\text { Yes } \\
\text { No }\end{array}$ & $\begin{array}{l}383 \\
127\end{array}$ & $\begin{array}{l}75.1 \\
24.9\end{array}$ \\
\hline $\begin{array}{l}\text { Previous complaint or problem from agriculture } \\
\text { work: } \\
\text { Beating \& kicking from supervisors or father } \\
\text { increasing working hours } \\
\text { Decreasing in money } \\
\text { fatigue } \\
\text { No complains or problems }\end{array}$ & $\begin{array}{c}121 \\
32 \\
30 \\
136 \\
191\end{array}$ & $\begin{array}{c}23.7 \\
6.3 \\
5.9 \\
26.7 \\
37.4\end{array}$ \\
\hline $\begin{array}{l}\text { Past hazards from agriculture work } \\
\text { Yes } \\
\text { No }\end{array}$ & $\begin{array}{l}225 \\
285\end{array}$ & $\begin{array}{l}44.12 \\
55.88\end{array}$ \\
\hline
\end{tabular}


Cont.

\begin{tabular}{|l|c|c|}
\hline Wearing safety clothes during work & 380 & 74.51 \\
Yes & 130 & 25.49 \\
\hline *If yes, what it is (more than one answer allowed) & 135 & \\
Gloves & 34 & 35.53 \\
Mask & 206 & 8.94 \\
Hat & 45 & 54.21 \\
plastic boots & 11.84 \\
\hline If No, why you don't use: & 13 & \\
I dislike it & 9 & 13.85 \\
There is no hazard & 90 & 6.92 \\
There is no money & & 69.23 \\
Unavailable & 257 & \\
\hline the supervisor(or father) provides these protective & 253 & 50.39 \\
clothes & & 49.61 \\
Yes & 219 & \\
No & 291 & 42.94 \\
\hline Are you having enough money from your work & 57.06 \\
\hline that permits you to purchase protective clothes & & \\
Yes & & \\
No & & \\
\hline
\end{tabular}

More than one answer was allowed $\bullet$

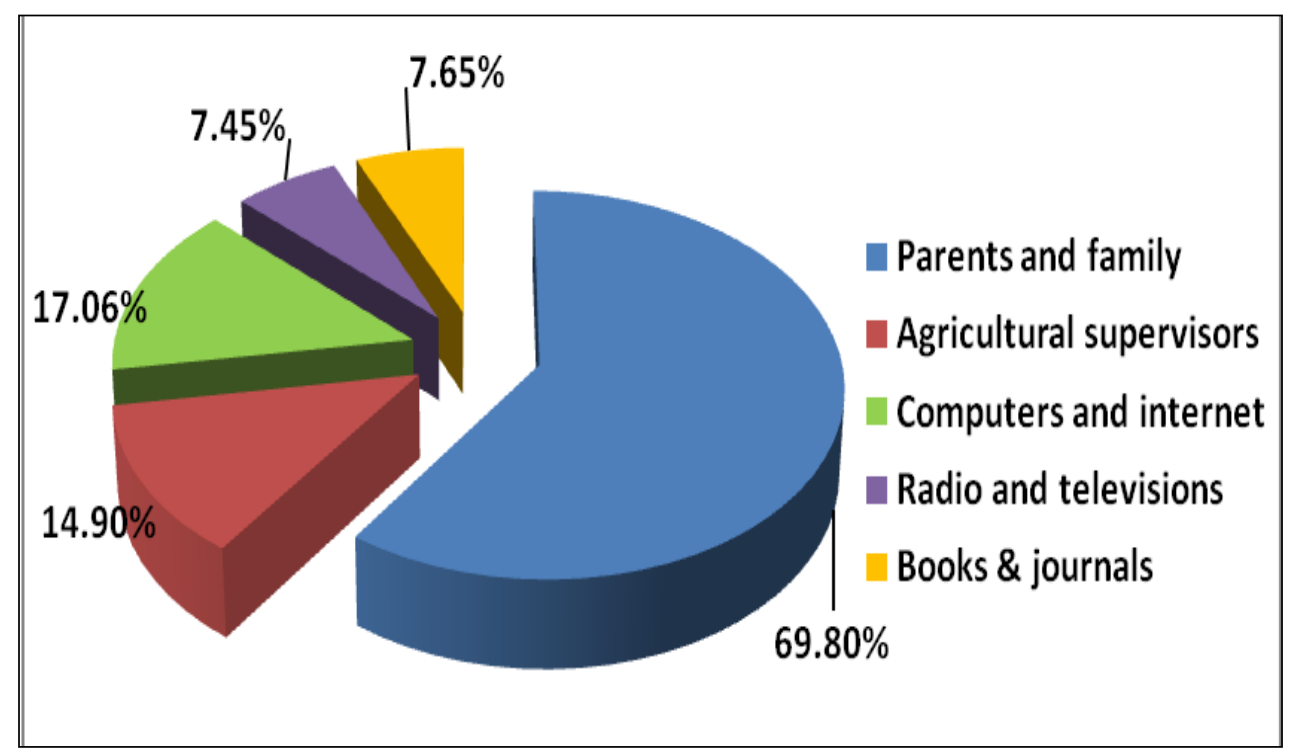

Figure (1)):- Distribution of studied students according to their responses regarding their sources of information about agriculture hazards. 
Table (3:- Distribution of studied students accords to their total score of knowledge for each agriculture hazards.

\begin{tabular}{|c|c|c|c|c|c|c|}
\hline \multirow{3}{*}{$\begin{array}{l}\text { Total score of student's } \\
\text { knowledge related to } \\
\text { agriculture hazards }\end{array}$} & \multicolumn{6}{|c|}{ Knowledge score } \\
\hline & \multicolumn{2}{|c|}{$\begin{array}{c}\text { High } \\
65 \% \text { \& above }\end{array}$} & \multicolumn{2}{|c|}{$\begin{array}{r}\text { Average } \\
50 \%-<65 \%\end{array}$} & \multicolumn{2}{|c|}{$\begin{array}{l}\text { Poor } \\
<50 \%\end{array}$} \\
\hline & $\mathbf{N}$ & $\%$ & $\mathbf{N}$ & $\%$ & $\mathbf{N}$ & $\%$ \\
\hline Physical hazards & 0 & $0.0 \%$ & 6 & $1.2 \%$ & 504 & $98.8 \%$ \\
\hline chemical hazards & 12 & $2.4 \%$ & 32 & $6.3 \%$ & 466 & $91.4 \%$ \\
\hline Mechanical hazards & 11 & $2.2 \%$ & 19 & $3.7 \%$ & 480 & $94.1 \%$ \\
\hline biological hazards & 0 & $0.0 \%$ & 1 & $0.2 \%$ & 509 & $99.8 \%$ \\
\hline Psychological hazards & 1 & $0.0 \%$ & 7 & $1.4 \%$ & 502 & $98.4 \%$ \\
\hline personal hazards & 6 & $1.2 \%$ & 32 & $6.3 \%$ & 472 & $92.5 \%$ \\
\hline
\end{tabular}

Table (4):- Distribution of studied students accords to their total score of knowledge about agriculture hazards.

\begin{tabular}{|c|c|c|c|}
\hline \multirow{2}{*}{\multicolumn{2}{|c|}{ Total Knowledge score }} & \multicolumn{2}{|c|}{ The sample $(\mathrm{n}=\mathbf{5 1 0})$} \\
\hline & & $\mathbf{N}$ & $\%$ \\
\hline High & $65 \% \&$ above & 0 & $0 \%$ \\
\hline Average & $50 \%-<65 \%$ & 4 & $0.8 \%$ \\
\hline Poor & $<50 \%$ & 506 & $99.2 \%$ \\
\hline \multicolumn{2}{|l|}{ Range } & \multicolumn{2}{|c|}{$0-56$} \\
\hline \multicolumn{2}{|c|}{ Mean \pm SD } & \multicolumn{2}{|c|}{$20.88 \pm 9.12$} \\
\hline
\end{tabular}




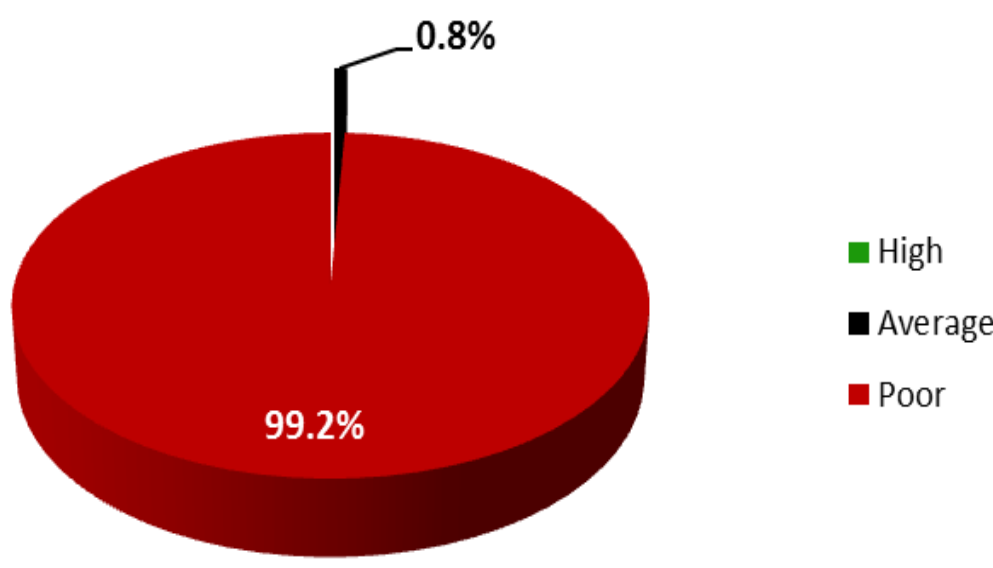

Figure (2):- Distribution of studied students accords to their total score of knowledge about agriculture hazards.

\section{Discussion}

Child labor is a persistent problem throughout the world, especially in developing countries. It is prevalent in rural areas of those countries where poverty is widespread. Child labor is an important global issue associated with poverty, unbalanced economic growth, inadequate educational opportunities, gender inequality, inadequate regulations to restrict child labor, and lack of public awareness. One out of six children in the world is involved in child labor, and nine out of ten children in rural areas are working in agriculture or are involved in similar activities. Many of the world's child laborers' in agriculture perform hazardous labour that can threaten their lives, health and general well-being ${ }^{(33-36)}$.

Agricultural work is dangerous. Children are doing work that is damaging their mental, physical and emotional development. Because children's bodies and minds are still growing and developing, exposure to workplace hazards and risks can be more devastating and long-lasting for them ${ }^{(37-39)}$.

In (2002), The International Labor Organization estimated that nearly 250 million children engaged in child labor around the world, the vast majority (70 
percent) were working in agriculture. Child agricultural workers, are exposed to toxic pesticides, and suffer high rates of injury from sharp knives and other dangerous tools. Their work is harsh, and violates their rights to health, education, and protection from work that is hazardous or exploitative ${ }^{(5)}$. The work that children perform in agriculture is often invisible and unacknowledged because they assist their parents or relatives on the family farm or they undertake piecework or work under a quota system on larger farms or plantations, often as part of migrant worker families ${ }^{(20)}$.

Seeing vulnerable children risking their lives and harming their health is disturbing and painful to everyone. Although child labor is globally recognized as a health problem, researches into the health impacts of child labor in Egypt have been limited to some urban areas ${ }^{(40,41)}$. Therefore the present study was initiated to study the knowledge of preparatory students working in agriculture about work hazards in order to clarify the magnitude of the problem and grasp the attention for necessary rapid solution. Although the Egyptian child low and the national low in many countries prohibit children from working before the age of fourteen, the present study revealed that the majority of the students' age was less than 15 years (table1). This finding is in agreement with Salem study (2004), in Mansoura about the effect of agriculture work on the health status of preparatory school children, which reported that the majority of working children were under 15 years ${ }^{(42)}$. Also Human Right Watch (2002) reported that children working in cotton pest in Egypt were between the ages of seven and twelve years ${ }^{(43)}$. The International Labor Office (2002), also reported that large proportion of working children were found in agricultural sector was aged between 5-15 years ${ }^{(44)}$.

As regard to gender the present study revealed that nearly three quarters were males and only one quarter were females (table1). This finding is in agreement with different studies; Bureau of International Labor Affairs (2008), reported that child labor is more frequent among boys than girls ${ }^{(45) .}$ Kotb et al. study about agricultural labor among school children in rural Assiut (2011), revealed that male students are 
more involved in agricultural work than female students $(60.2 \%$ versus $39.8 \%)$ (46). This finding could be explained by the norms of our society as females' help their mothers in household activities and do their homework. In contrast a survey carried by ILO in 26 countries (1997) on children at work, reported that approximately three quarters of girls compared to more than two thirds of boys were engaged in agricultural activities ${ }^{(47)}$. The same finding was also reported by a study done in Sudan (2001), which reported no sex differential, where females as well as males were working mainly in the traditional sector in agriculture ${ }^{(48)}$.

As regard to the number of persons living with the students, the present study revealed that more than three quarters of working students come from large families with five persons and more (table1). This may be attributed to the nature of life in rural extended families which living together and also to the rising inflation and economic burden. This clarify the burden that exists on parents of large family number that lead them to employ their children. The same finding was reported by other studies. Haggag study about the impact of child's labor on the health status in Alexandria (1995), reported that most of the working children were from large families (49). Boer (2005), in the Philippines stated that rural houses stand closely together and are overpopulated with average family size of eight to ten people ${ }^{(50)}$. El-Gilany et al., studies the epidemiology and hazards of student labor in Mansoura (2007), stated that working students were from large families ${ }^{(41)}$.

The present study revealed that more than one third of the studied students were the first child in the birth order while nearly one quarter was the second and third order (table1). This can be explained that, parents may view that the first child by taking part in agricultural work activities learn responsibility, reliability, work ethics, new skills and coping with problems. This in contrast with Haggag study (1995), reported that most of the working children were the second or third order (49). Kotb et. al., study (2011), also revealed that more than half of the working children were from the second birth order or more ${ }^{(46)}$.

In relation to mothers' education, the present study revealed that nearly half 
of them were either illiterates or read and write, and the majority of the studied student mothers' occupation was housewife (table1). This finding is in agreement with Kotb et. al., study (2011), who revealed that a greater percent of mothers fall in the illiterate category and most of the student's mothers were housewives ${ }^{(46)}$.

Regarding the family income, the present study revealed that more than half of the studied students mentioned that the income was just sufficient while only $21.2 \%$ mentioned that income was insufficient and the majority of the studied students' source of income was from fathers' work (table1-4). This finding is in agreement with different studies; Matter study about child labor in Egypt: Scope and appropriate legal responses (2007), Itani study about child labor in Egypt (2009), and Bureau of International Labor Affairs(2008), who reported that most of the working children came from low income families and the source of their income was from fathers' work ${ }^{(14,45,51)}$.

As regard to the students past experience in agricultural work (table 2 ), the present study revealed that more than half of the studied students started work before 10 years old. This finding is below the minimum age (13) years in seasonal agricultural work in Egyptian low ${ }^{(52,53)}$. This may be explained by that agriculture remains the primary occupation of adults in rural areas and fathers prefer to take their very young children especially boys for gaining experience. Similar finding were reported by Matter (2007), who stated that children started work from 6-14 years in Egypt, Itani (2009), reported that working children started work at an early age from7-15 years, and ElSamman et. al., (2008), stated that majority of children started work at the age of 8 -9 years ${ }^{(14,51,54)}$.

Regarding working during school, the present study revealed that more than two thirds of studied students didn't work during school. In relation to the effect of work on study, the majority of the students mentioned that there was no effect on their study.Among those who reported that work affected their study, the majority reported it in the form of failure in the study (table 2). This finding is in concomitant with Kotb et. al., (2011), study which stated that student labor has a profound effect on education and achievement, as $63 \%$ ( 
out of 332 sample) of working students failed in the previous year and 69\% of working students successed with failure in some subjects. This was also corroborated with research conducted by UNICEF (2008), and its conclusion was that Labor often interferes with children's education ${ }^{(55)}$.

As regard to the reasons for working in agricultural work, the present study revealed that slightly less than half of the studied students reported that the main reason was to help their fathers' in the work and nearly one quarter reported that their reason was to be dependent on themselves. The present results also stated that two thirds of the studied students worked in their families own fields (table 2). This may be explained by that families don't want to pay for outside help from other farm workers because all family including children work in the field. This finding is in agreement with Kotb et. al., (2011), study who stated that the most important cause of the students' work was helping their fathers in the work and sharing in the family expenses and about two thirds of the working children were unpaid. The survey on social, health status and educational achievement of adolescent in Egypt (1998), indicated that for working adolescent (10-19years), the most important reason for work was to help the family (without pay).This pattern is prevalent in rural areas ${ }^{(46,56)}$.

As regard to the reasons for choosing agricultural work, the results shows that nearly half of the studied students, choosing the agricultural work because it's fathers' profession, and the majority of the studied students, their nature of work was picking crops .It also shows that nearly half of the studied students were working during summer \& vocations (table 2) .This finding is in consistent with Itani study (2009),who stated that most child workers in Egypt were employed in seasonal work in cotton fields and during summer holiday months ${ }^{(14)}$. These findings were in consistent with other studies reported by United State Department of Labor studies about the worst forms of child labor in Egypt in 2007, 2006 and in $2005^{(18,21,57) \text {. }}$

As regard to the working hours per day, the result of the current study revealed that less than half of the studied students worked less than four hours and about one third of them worked 
more than 6 hours. The present study also revealed that the entire studied students were taking a rest period during the work, nearly half of them took half an hour (table 2). This finding is in agreement with Kotb et. al., (2011), who stated that the majority $(80 \%)$ of the working students worked not more than three hours (1to 3 hours per day) and about (75\%) took a rest period of half an hour ${ }^{(46)}$. In contrast of this, Mathews et al., (2003), found that children worked about 12 hours per day ${ }^{(58)}$. In 2002, a survey about child labor in agriculture conducted by Human Rights Watch in developing countries revealed that the vast majority of working children worked between nine and thirteen hours per day ${ }^{(59)}$.

The result of the current study revealed that more than one third of the studied students had no complain or problem from agricultural work, while nearly one quarter of them complained from fatigue, and the same percentage complained of beating \&kicking from their supervisors or fathers (table 2). In contrast of this finding in Salem study (2004), found that all working children except $1.3 \%$ reported one or more physical complaint affecting the different body system ${ }^{(42)}$.

As regard to the past exposure to hazards from agricultural work, the result of the current study revealed that almost one half of the students had past hazard from the work (table 2). Similar finding was reported in Salem study (2004), where more than half of the working males were exposed to work hazards ${ }^{(42)}$.

In relation to wearing safety clothes, the result of the current study revealed that nearly three quarter of the students wear safety clothes and this was in the form of hat for nearly half of them. More than two thirds of the studied students who did not wear safety clothes reported because they were unavailable (table 2). This finding can be explained by that a hat is a cheap personal protective device. In addition the working children have lack of knowledge about expected hazards and their effect on human health .This highlight the need for educational training program about the importance and quality of using personal protective devices. Salem study (2009), stated that about $12.9 \%$ were using boot and mentioned that safety equipments designed for adults often doesn't fit 
children and were difficult for them to handle ${ }^{(15)}$.

Work hazards affect children to greater degree than adult, in some cases causing irreversible harm to their physical development with serious consequences for their futures. Thus young workers are susceptible to all the dangers exposure faced by adults when placed in the same environment. However, children differ biologically from adults in their anatomical, physiological, and psychological characteristics because of their process of growth and development. Therefore, exposure to hazards that affect adults can affect children much more strongly ${ }^{(60,61)}$.

The present study revealed that most of the studied students their source of information was from their parents and family and the majority of studied students had poor knowledge score regarding the different agriculture hazards. The majority (99.2\%) of them also had poor knowledge scores regarding the total scores of agricultural hazards (figure 2 and table 3,4). This can be explained by that there is lack of health knowledge among parents and family of the studied students regarding agricultural health hazards.
Furthermore, if they knew the hazards, they had poor knowledge about its effects. Lack of students' knowledge highlight the gaps of school curriculum regarding scientific information on long-term health effects of child labour. World Health Organization in studding child labor and adolescent workers (2005), reported that two thirds of the students lacked any knowledge or had wrong ideas which probably reflect misconceptions of the general public about ill-health-effects of work (68\%) (62). By Contrast Ajayi (2004), in studying rural children's knowledge of hazards associated with farming in Oyo State mentioned that $67.47 \%$ had a moderate or average knowledge of hazards associated with farming while $20.08 \%$ had a high level of knowledge of hazards and dangers associated with farming ${ }^{(63)}$.

Finally the present study revealed that most of the studied students had poor knowledge score regarding the different agriculture hazards and their main source of information was their parents and families. This directs the lights toward nurse's role toward improving rural children and their families' knowledge about the occupational 
health hazards especially agricultural work.

\section{Conclusion}

Based on the findings of the present study it can be concluded that most of students working in agriculture were males and were under fifteen years old. The main reason for working in agricultural work was to help their fathers' in the work and nearly one quarter reported to be independent. Furthermore, almost one half of the studied students reported working only on summer and vocation for less than four hours per day and about one third of them worked more than 6 hours. Nearly one quarter of the studied students complained from fatigue, and beating \&kicking from their supervisors or fathers. Nearly two thirds of the studied students who were not wearing safety clothes reported that they were unavailable.

In addition, the majority of studied students identified the elements of different agriculture hazards (physical, chemical, mechanical, biological and psychological) but had lack of knowledge regarding its health effects. Therefore, the majority of studied students had poor total knowledge score regarding the different agriculture hazards. Most of the studied students their main source of information was from their parents and family. This revealed a lack of health knowledge of parents and families of the students regarding the agricultural health hazards.

\section{Recommendations}

\section{Based on the findings of the present study, the following are \\ recommended:-}

1. Development of data base on child labor in agriculture, through performing comprehensive epidemiological surveys to determine their number and nature of hazards, injuries or illnesses suffered by children. This should be used to plan a protection measures and training program.

2. Ensure that all working children receive full information and training from their employers and health workers about occupational hazards related to agricultural work. such training should be conducted regularly and be understandable by children.

3. Health education needs to be integrated with school curriculum to 
focus the attention of students about the information on prevention of work related health hazards and accidents.

4. Suitable protective equipments and clothes for children should be provided by the employers, and children should be covered by medical and social insurance.

5. Community health nurses as health professionals, social workers and all community sectors should ask for enforcing and applying existing laws on child labor which supervise and control child labor in agriculture through all means as community organizations and media.

6. Community health nurses working in rural health units should receive special training on agriculture hazard

\section{References}

1- Ball J and Binder R. Child health Nursing. United States: Reasons prentice Hall, 2006; 150-168.

2- Human Rights Watch. Failure to protect child from farm workers. United States: Human Rights Watch reports, 2000; 1-4.

3- Fares J and Raju D. Child labor across developing world. USA: World Bank Report, 2007; 1-4.
4- International labor organization. International programs of elimination of child labor. USA: ILO Reports, 2008; 1-2.

5- Rural employment team .Work for eliminating child labor in agriculture. United Nation: Food and agricultural organization, 2010;1-6.

6- Iskander L. Educating working children. Cairo, Egypt: Al Aharms Weekly, 2006; issues No, 813.

7- Assad R. The effect of child work on school enrollment in Egypt. Minnesata University; Economic research forum for the Arab Counties, Humphrey Institute of Public Affairs, 2001; 8 (2): 3-9.

8- Mccurdy $S$ and Carrol D. Agricultural injury. American Journal of Industrial Medicine, 2000; 38:463.

9- Marlow D and Redding B. Pediatric Nursing.$^{\text {th }}$ ed. New York: Elsevier / WB Sounders Company, 2007; 3-20.

10- Marlenga B, Pickett $W$ and Berg R. Agricultural work activities reported for children \& Youth. North America: Journal of 
agriculture's safety and health, 2001; 7: 241-252.

11- Marlenga B, Pickett $W$ and Berg R. Assignment of work involving farm tractor to children. North America. Industrial medicine: 2001; 40: 15-22.

12- Dourdillon M. Child labor and education: A study from southeastern Zimbabwe. Journal of social development 2000; 15 (2): 5 33.

13- One world guide. Child labor. London: UEL University of East London, $\quad 2010 ; \quad 1-7$. http://uk.oneworkld.net/guides/chil dlabor.

14- Itani N. Child labor in Egypt. Master thesis, Faculty of Humanities, University of Southern Denmark. 2009;1-4.

15- Salem M. Impact of applying safety measures on the occurrence of agriculture hazards among preparatory school pupils. Doctoral thesis. Faculty of nursing, Alexandria University, 2009.

16- Egypt- United States Department of labor .2006 Findings on the worst from of child labor. Egypt:
U.S. Department of labor reports. 2007; 1-5.

17- World Bank Surveys. Child Economic activity and school attendance rates. Egypt, Unicef and UCW analysis of ILO Reports, 2007.

18- United State Department of labor .Country Reports. Egypt: U.S. Department of labor Reports, 2006.

19- U.N. Office for the coordination of Humanitarian Affairs. Egypt: children of the quarries. Integrated regional information Networks (IRIN) Cairo, 2008;219-223

20- International

Labor Organization. Harvest. Geneva: Bureau for worker's activities, 2002; 1-5.

\section{1- United State Department of} labor. 2004 Findings on the worst forms of child labor-Egypt. Egypt. U.S. department of labor reports, 2005; 1-6.

22- Human Rights Watch. Underage and unprotected: child labor in Egypt's cotton fields. Egypt: HRW reports. $2001 ; 1-21$.

23- Human Right Watch. Status of child labor practice and minimum 
age for employment. Egypt: HRW Reports, 2004; 76, 117; 421.

24- Human Right Watch. Child labor laws grossly violated in Egypt. Egypt: HRW reports; 2001; 1-2.

25- The World Bank group in Egypt. A future without child labor. Middle East and North Africa: The World Bank group report, 2009.

26- International labor organization .What is child labor. United State; International labor organization reports, 2008. http://www.child labor. In

27- Human Rights Watch. Child labor in agriculture. New York: Human Rights Watch reports, 2002; 1-4.

28- Watkins D, Cousins $J$ and Whitehead D. Public health and community nursing. 3rd ed. China: Elsevier Limited, 2010; 230-717.

29- Levy $B$ and Wegman D. Occupational health: Recognizing and preventing work related disease and injury. Philadelphia: Lippincott Williams and Wilkins, 2000; 689-748.

30- Department of labor. Child requirements in agricultural occupation. United States: Fair labor standers Act, 2007;1-9 on http://www.dol.gov/esa/whod /regs/compliance/child labor/ 20 pdf.

31- Rogers B. Occupational and environmental Health Nursing. $2^{\text {nd }}$ ed. United States: Saunders, 2003; 177-178.

32- Kirkhorn $S$ and Schenker $M$. Human health effects of agricultural and illness. Journal of Public health, 2001; 1-16.

33- International Labor Organization. Harvest. Geneva: Bureau for worker's activities, 2002; 1-5.

34- Fassa A , Parker D , and Scanlon T .Child labour: A public health perspective. United State: Oxford University Press, 2010; 3942.

35- Human Right Watch. ILO members urged to take action on child labor in agriculture. United States: HRW reports, 2002; 1-4.

36- International Labor Organization .Facts on child labor .ILO (2004): At website:www.ilo.org/childlabor.

37- Datta P. Pediatric Nursing. New Delhi: Jaypee Brothers, 2007; 3031. 
38- Smith C and Maurer A. Community / public health nursing: Health for families and population. USA: Elsevier, 2005; 758.

39- Hurst, P. Health and child labor in agriculture. Food Nutrition Bulletin, 2007; 28(2):364-371.

40- Kishk F, El-Masry A, Abd-Allah S. and Gaber H. Vulnerability of working children to environmental health risks: a case study in a village in rural Egypt. Global Forum for Health Research, (Forum 8). Mexico city, Mexico, 16-20 November 2004.

41- El-Gilany A, Khalil A. and. ElWehady, A. Epidemiology and hazards of student labor in Mansoura, Egypt. Eastern Mediterranean Health Journal, (2007); 13(2): 347-363.

42- Salem N. The effect of agriculture work on the health status of preparatory school children. Master degree in community health nursing .Faculty of Nursing. Alexandaria University. 2004.

43- Human Right Watch. Backgrounder: child labor in agriculture. HRW Word Report.
2002. Available http://hrw. Org/ back grounder/ crop/back06/0

44- International labor office. A future without child labor Global report under the follow up to ILO declaration on fundamental principles and rights at work. Switzerland: Geneva, International Labor conference 90th Session, 2002.1-35.

\section{5- Bureau of International Labor} Affairs. Study of child labor in Haiti's agricultural sector: A study of Children in the rural centre department. Washington: Macro International Inc, 2008; 1-147.

46- Kotb S, Mohamed A, Abdel Khalek E and Yones D. Agricultural Labor among School Children in Rural Assiut. Egypt Life Science Journal, 2011; 8(2).117

$$
\text { Available }
$$
at:http://www.lifesciencesite.com.

47- Forastieri $v$.Children at work: health and safety risks .Geneva: International Labor Organization, 2002; 5-7.

48- Omar A. Workshop on the analysis of poverty and its determinants in the MENA Region. Northern Sudan: Economic 
research forum for the Arab countries and the World Bank, 2001; 31-5.

49- Haggag M. The impact of child's labor on the health status in Alexandria .Degree of doctor thesis .Faculty of Nursing, Alexandria University.1995.

50- Boer J. Sweet hazards: Child labor on sugarcane plantations in the Philippines. Philippines: Terre des Hommes ,Netherlands, 2005;1-41.

51- Matter M. Child labor in Egypt: Scope and appropriate legal responses. Iran: Gozar, 2007; 1-5.

52- Unicef. Child labor, what could be done? .Egypt: Unicef- Egyptcountry office, 2002; 1-10.

53- Government of Egypt and United Nations children's fund. The situation of Egyptian children: A rights based analysis. Cairo: Social research center, 2001.

\section{4- El-Samman G, Mahmoud A, Abo}

El-Matty $G$ and Ismail A. Impact of children labor on psychosocial development of school age children in Ismailia governorate. Assiut University bulletin for environmental researches, 2008; 11(1):99-114.
55- UNICEF. Statistics by Area/Child Protection. Available Online at http://www.childinfo.org/ labour.html Accessed on2008; 826-08.

56- Working children in Egypt. http/www.aucegypt.edu/src/childla bor /factors.htm.

\section{7- United State Department of} Labor. 2007 findings on the worst forms of child labor .Egypt: Department of labor report, 2008;15. http://www.unchr.org/reworld/doci d/48caa48dc.html.

58- Mathews R, Reism C, and Iacopino V. Child labor: A matter of health and human rights. Journal of Ambulance Care Manage, (2003); 26(2):181-182.

59- Human Right Watch. ILO members urged to take action on child labor in agriculture. United States: HRW reports, 2002; 1-4.

60- Kumers $S$ and Sengupta G. Environmental and occupational health problems of child labor: some issues and challenges for future. Community medicine, 2009; 28 (2): 143-148. 


\section{1- International Labour}

Organization .Rooting out child

labour from cocoa farms, Paper No.

2: Safety and health hazards. Italy,

International Labour Office, 2007;

$1-32$.

62- World Health Organization

.Child Labor \& Adolescents

Workers. Geneva: Switzerland,

2005; 9: 1-16.

63- Ajayi A and Jibowo A .Determinants of Rural Children's Knowledge of Hazards Associated with Farming in Oyo State.

Nigeria: Department of Agricultural Extension and Rural Sociology J, 2004; 9(3): 195-200. 